\title{
Genotype by environment interaction in different birth seasons for weight at 240,365 and 450 days of age in Tabapuã cattle
}

\author{
Severino Cavalcante de Sousa Júnior ${ }^{1}$, lara Del Pilar Solar Diaz², Karina Rodrigues dos \\ Santos ${ }^{1}$, José Ernandes Rufino de Sousa ${ }^{1}$, José Lindenberg Rocha Sarmento ${ }^{1}$, Raimundo \\ Martins Filho ${ }^{3}$
}

\begin{abstract}
${ }^{1}$ Universidade Federal do Piauí, BR 135, km 03, Planalto Horizonte, 64900-000, Bom Jesus, PI, Brazil.
2 Universidade Estadual "Júlio de Mesquita" - UNESP, Av. Prof. Paulo Donato Castellane, s/n, 14884-900, Jaboticabal, SP, Brazil.

${ }^{3}$ Universidade Federal do Ceará, Av. Tenente Raimundo Rocha s/n, Cidade Universitária, 63040-360, Juazeiro do Norte, CE, Brazil.
\end{abstract}

\begin{abstract}
The objective of this study was to evaluate the effect of genotype by environment interaction (GEI) on the weight of Tabapuã cattle at 240 (W240), 365 (W365) and 450 (W450) days of age. In total, 35,732 records of 8,458 Tabapuã animals which were born in the state of Bahia, Brazil, from 1975 to 2001, from 167 sires and 3,707 dams, were used. Two birth seasons were tested as for the environment effect: the dry (D) and rainy (R) ones. The covariance components were obtained by a multiple-trait analysis using Bayesian inference, in which each trait was considered as being different in each season. Covariance components were estimated by software gibbs2f90. As for W240, the model was comprised of contemporary groups and cow age (in classes) as fixed effects; animal and maternal genetic additive, maternal permanent environmental and residual were considered as random effects. Concerning W365 and W450, the model included only the contemporary aged cow groups as fixed effects and the genetic additive and residual effects of the animal as the random ones. The GEI was assessed considering the genetic correlation, in which values below 0.80 indicated the presence of GEI. Regarding W365 and W450, the GEI was found in both seasons. As for post-weaning weight (W240), the effect of such interaction was not observed.
\end{abstract}

Key Words: Bayesian inference, beef cattle, genetic correlation, multiple-trait analysis

\section{Introduction}

In the animal breeding field, one of the main objectives is to develop and identify genotypes that present consistent economic performance in different production systems. To achieve this objective, different effects have been tested, and one of them, which has become the focus of lots of discussion until nowadays, is the genotype by environment interaction (GEI), which has already been defined as important in different Taurus breeds (Paula et al., 2009).

In Zebu cattle, the GEI was thought not to be important, since those breeds are recognized as adapted to different types of environments. However, the GEI effect was noticed to be important for the country and even among regions (Diaz et al., 2011a, 2011b). Taking into account that Brazil is a country in which it is possible to observe distinct types of environments with heterogeneous systems of cattle raising (Lopes et al., 2008), the presence and the importance of GEI evaluation seems to be justified.

Considering such diversification, separating the effects in the evaluation is necessary to explain how this kind of variability plays an influence on estimates of breeding values (Ferraz Filho et al., 2001).
The Brazilian herd is formed by Zebu cattle and the Tabapuã breed is one of the breeds that often increases, with a total of 140,454 animals (ABCZ, 2010), which gives a significant importance to this breed concerning the Brazilian chain of beef cattle and also highlights the relevance of conducting studies to evaluate all types of performance in the Brazilian environment (Sousa Júnior et al., 2010, 2011).

The northeast region of Brazil presents diversified kinds of scenery when it comes to raising cattle, which can lead to the change of genetic expression of the animals in the different environments to which they is exposed. Furthermore, both the lack of a standard production system of beef cattle in the northeast region and the variety of those systems are connected to the differences of climate, economical and historical conditions, not to mention their connection to the availability of natural resources that end up directly affecting the animal performance.

Thus, the objective of this research was to evaluate the influence of different birth seasons on Tabapuã animals at 240,365 and 450 days of age raised exclusively on pasture using genotype by environment approach. 


\section{Material and Methods}

This study utilized 40,238 pieces of information of weight at 240 (W240), 365 (W365) and 450 (W450) days from a herd of 7,778 animals of the Tabapuã breed in the states of Bahia, Alagoas, Sergipe, Minas Gerais, Maranhão and São Paulo, Brazil, born between 1975 and 2001, obtained from Associação Brasileira de Criadores de Zebu (ABCZ), with the objective of estimating the importance of the effect of the genotype by environment interaction in the dry (D) and rainy (R) birth seasons.

Only animals that were raised exclusively on pasture were considered in the evaluation. The rainy and dry birth seasons were classified considering the period from October to March and April to September, respectively.

Combining the information on season and trait, six environmental groups (EG) were formed: W240_R; W240_D; W365_R; W365_D; W450_R and W450_D. For each environmental group, the analyzed trait (W240, W365 and W450) was considered as a different one (Table 1).

The GLM procedure of software SAS (Statistical Analysis System, version 9.1), was used to define the important effects to be included in contemporary groups, which are the concatenation of feeding standard, year of birth, sex and herd. Contemporary groups that had fewer than three observations were excluded from the analysis and so were animals with inconsistent information. The final pedigree used in the relationship matrix was formed by information on the animal, sire and dam, resulting in a total of 8,193 animals.

Covariance components as for the three traits evaluated were obtained using software gibbs2f90 (Misztal, 2010), which provided two multi-trait analyses. Concerning the first one, all the traits were considered the same in all environments (EG), and in the second one, in each EG, the trait was treated as distinct.

The general model for W240 included contemporary groups and cow age (in classes) as fixed effects. The animal and maternal additive genetic, maternal permanent environment and also the animal residual effects considered

Table 1 - Descriptive analysis of the environmental groups as for the three evaluated traits

\begin{tabular}{lcccccc}
\hline $\begin{array}{l}\text { Descriptive } \\
\text { analysis }\end{array}$ & \multicolumn{5}{c}{ Environmental groups } \\
\cline { 2 - 7 } & W240_R & W365_R & W450_R & W240_D & W365_D & W450_D \\
\hline $\mathrm{N}$ & 4,253 & 2,981 & 2,546 & 2,462 & 1,829 & 1,421 \\
$\bar{x}$ & 188.33 & 228.81 & 276.44 & 199.70 & 229.42 & 257.21 \\
$\mathrm{SD}$ & 35.79 & 43.24 & 52.35 & 36.89 & 44.34 & 54.11 \\
\hline
\end{tabular}

W240, W365 and W450 - weights at 240,365 and 450 days of age, respectively. $\mathrm{R}$ - rainy season; $\mathrm{D}$ - dry season; $\mathrm{N}$ - number of observations; $x^{-}$- means; $\mathrm{SD}$ - standard deviation. as random. To W365 and W450, the general model included the contemporary groups and cow age as fixed effects and the animal additive genetic and residual as random effects.

The general model can be written as follows:

$$
y=X \beta+Z_{a} a+Z_{m} m+Z_{p} p+e
$$

In which $\mathrm{y}=$ vector of the observations (traits evaluated); $\beta=$ vector of the fixed effects; $a=$ vector of the animal genetic additive effect; $m=$ vector of the maternal genetic additive effect; $p=$ vector of maternal environmental effect; e = residual vector; $X, Z_{a}, Z_{m}$ and $Z_{p}=$ incidence matrix that relate $\beta, a, m$ and $p$ to $y$. It was assumed that $E[y]=$ $\mathrm{X} \beta ; \operatorname{Var}(\mathrm{a})=\mathrm{A} \otimes \mathrm{G}_{\mathrm{a}}, \operatorname{Var}(\mathrm{m})=\mathrm{A} \otimes \mathrm{G}_{\mathrm{m}}, \operatorname{Var}(\mathrm{p})=\mathrm{I}_{\mathrm{Nm}} \otimes \mathrm{G}_{\mathrm{p}}$ and $\operatorname{Var}(\mathrm{e})=\mathrm{I}_{\mathrm{N}} \otimes \mathrm{R}$, in which $\mathrm{I}_{\mathrm{N}} \otimes \mathrm{R}, \mathrm{G}_{\mathrm{a}}=$ animal genetic additive covariance matrix; $\mathrm{G}_{\mathrm{m}}=$ maternal additive covariance matrix; $G_{p}=$ genetic matrix of maternal environmental effects; $\mathrm{R}=$ residual covariance matrix; $\mathrm{A}=$ relationship matrix; I = identity matrix; $\mathrm{Nm}=$ number of dams with measures; $\mathrm{N}=$ number of animals with measures and $\otimes=$ direct product between matrices. Vectors $\mathrm{a}, \mathrm{m}, \mathrm{p}$ and were considered as independent.

Vectors $\beta$ and a were named as location parameters from a conditional distribution $\mathrm{y} \mid \beta, \mathrm{a}, \mathrm{m}, \mathrm{p}$. As a priori to $\beta$, a uniform distribution was considered, reflecting a previous knowledge about this vector. To a, a multivariated normal distribution was assumed as the priori with mean 0 and variance $G_{a} \otimes A$ to all the multiple-trait analyses. To $m$ and $\mathrm{p}$, a multivariate normal distribution was also assumed with mean 0 and variance $G_{m} \otimes A$ and variance $G_{p} \otimes I$, respectively.

For all the other components, a wishart distribution was assumed as a priori (Van Tassel \& Van Vleck, 1996).

In both multiple-trait analyses, Gibbs chains of $1,000,000$ samples were generated: the first 50,000 were discarded and the chains after those samples were kept to do the inferences about the posterior distribution, using one at every 50 samples. The evaluation of chains was done by package BOA (Smith, 2007) of software R, in which the convergence and dependency between samples were evaluated using the test of Heidelberger \& Welch (1983). The importance of the genotype $\times$ environment interaction was verified through genetic correlation $\left(\mathrm{r}_{\mathrm{g}}\right)$. Interactions were considered important if the $r_{g}$ values among the EG were below 0.80 .

\section{Results and Discussion}

The heritability estimates of growth traits evaluated at 240 (W240), 365 (W365) and 450 (W450) day-old cows in both birth seasons, rain (R) and dry (D), in all different 
states studied (Table 2), were similar. Higher estimates were obtained during the rainy season for W365 and W450. These high estimates could indicate that most of the phenotypic variation observed in the studied population is related to the additive effects of genes, which can provide important gains through selection.

The differences of heritability estimates observed between birth seasons were 0.02 for W240, 0.15 for W365 and 0.09 for W450. The highest difference was obtained for W365, indicating that a higher genetic variability between seasons can be found during this life period of animals. However, these differences in estimates indicate that the phenotypic performances of the progenies from the same sire are different depending on the seasons.

Similar results for traits at different ages have been found in Tabapuã animals (Sakaguti et al., 2003; Dias et al., 2005, 2006; Sousa Júnior et al., 2010, 2011) and also in Nellore cattle at lower magnitudes (Alencar et al., 2005; Mascioli et al., 2006; Lopes et al., 2008).

The genetic correlation estimates for W240, W365 and W450 (Table 2) presented values ranging from 0.53 to 0.88 , which classifies those estimates as being from medium to high. The highest genetic correlation value was obtained between W365_D and W450_D (0.88) and also between W365_D and W450_D (0.79), which indicates a higher genetic variability between traits, no matter the birth season considered, when compared with the other traits evaluated. However, traits W240_R and W240_D showed higher values of genetic correlation when compared with W450_R, W240_D and W365_D, indicating that selection for higher weight gains could be more efficient if performed at earlier ages, close to 365 days of age. Robertson (1959) reported that genetic correlation values below 0.80 indicate the presence of genotype $\times$ environment interaction (GEI).

Genetic correlation values ranging from low to medium magnitude, means that genes related to growth in one birth season are not the same genes related to the expression of the same trait in another season. Those results are similar to those found by Fridrich et al., (2003) which also worked with Tabapuã animals in four regions of Brazil, evaluating weights at 205, 365 days of age, where GE was found only where GE was found only between region northeast to south and southeast regions, with genetic correlations ranging from -0.86 and 0.51 , respectively.

Lower results of genetic correlations for other breeds of zebu cattle were described by Alencar et al. (2005) and Lopes et al. (2008) in Nellore cattle; Pereira et al. (2006), concerning Caracu cattle; and for Canchim cattle.

The heritability and genetic correlation estimates presented by the evaluated traits (W240, W365 and W450) in this study when not considering the effect of GEI (Table 3) point to magnitudes of heritability ranging from 0.43 to 0.48 , in other words, with a medium magnitude, with a tendency to an increase when the age of the animals does as well. Similar results have been found by Dias et al. $(2005,2006)$ and Sousa Júnior et al. $(2010,2011)$, who also worked with Tabapuã animals.

The range of the genetic correlations between the studied traits ( 0.73 to 0.88 ) (high magnitude) are similar to results found by Sakaguti et al. (2003), Dias et al. (2006) and Sousa Júnior et al. $(2010,2011)$. These results indicate that according to the direct heritability estimates and the genetic correlations, there is enough genetic variation to obtain a higher genetic gain if an individual selection is done at weights after weaning, since, during this period, it will be possible to identify animals of superior genetics.

It is important to highlight that when selections related to animal life are done later, a higher chance of achieving an increase of mature weight of cows is expected, since the correlation between weights after yearling with mature weight is considered high and, moreover, this kind of increase is not always desirable (Sousa Júnior et al., 2010).

It is possible to verify that heritability estimates of W240_D, W365_D and W450_D with the estimates from W240, W365 and W450, i.e., between estimates during the dry season and estimates without GEI, were more similar when the comparison is done between the same traits during the rainy season (Tables 2 and 3).

Table 2 - Mean and standard error (parentheses) of heritability estimates and genetic correlations (above the diagonal) between the three traits during both birth seasons

\begin{tabular}{lccccc}
\hline & W240_R & W365_R & W450_R & W240_D & W365_D \\
\hline W240_R & $0.44(0.05)$ & $0.69(0.12)$ & $0.71(0.11)$ & $0.78(0.06)$ & $0.71(0.10)$ \\
W365_R & & $0.58(0.06)$ & $0.79(0.13)$ & $0.53(0.09)$ & $0.66(0.08)$ \\
W450_R & & $0.59(0.08)$ & $0.59(0.09)$ & $0.64(0.09)$ & $0.64(0.10)$ \\
W240_D & & & $0.42(0.04)$ & $0.73(0.13)$ & $0.66(0.10)$ \\
W365_D & & & & $0.08)$ \\
W450_D & & & & $0.65(0.13)$ & $0.05)$ \\
\hline
\end{tabular}

W240, W365 and W450 - weights at 240, 365 and 450 days of age, respectively.

$\mathrm{R}$ - rainy season; D - dry season. 
The heritability estimates of the characteristics of the rainy season had higher magnitudes when compared with the characteristics of the dry period, (Table 2), with the heritability with no use of GEI effects (Table 3) and with the results obtained in the literature, as reported by Sousa Júnior et al. (2010), who, working with the same database, described estimates of $0.31,0.40$ and 0.44 using single and bi-trait models comparing them with random regression models (RRM).

The results concerning genetic correlations (Tables 2 and 3) show similar variations, with maximum points of 0.88 and with minimum points differing from 0.53 to 0.73 between the analyses that consider both effect of the presence and absence of GEI, respectively. The biggest differences of genetic correlations estimates were found for W240 with other weights in both seasons, which could be explained by a bigger difference between those weights related to the other traits. According to Sousa Júnior et al. (2010), in Tabapuã cattle, when differences between weights increase, so do genetic correlations. Similar values were found by Mascioli at al. (2006).

In this study, genetic correlations values below 0.80 were found, and according to Cardelino \& Rovira (1987) there is genotype $\times$ environment interaction when the genetic and the environment effects do not combine additively. An example is the change in the order of animal classification when the environment changes.
Table 3 - Mean of heritability estimates (diagonal) and genetic correlations (above the diagonal) and standard error (parentheses) of the three traits evaluated when an analysis that does not consider the GEI effect is conducted

\begin{tabular}{lccr}
\hline & W240 & W365 & W450 \\
\hline W240 & $0.43(0.05)$ & $0.75(0.04)$ & $0.73(0.04)$ \\
W365 & & $0.44(0.06)$ & $0.88(0.02)$ \\
W450 & & $0.48(0.08)$ \\
\hline W240, W365 and W450 - weights at 240, 365 and 450 days of age, respectively.
\end{tabular}

The a posteriori distribution of the heritability estimates (Figure 1) shows a better understanding and details about heritability estimates. The posterior distribution has a tendency of being a normal one with three traits evaluated, with a higher dispersion on W365_R; W450_R; W365_D and W450_D. The observation of the graphics allows us to infer, by the intersection of the densities, that the rainy period, overall, shows the highest heritability estimates if compared with the dry season for all the traits.

The posterior distribution of W240_R and W240_D presented many more similarities with each other than when compared with the other traits.

One can observe that the distribution of W240_D was always similar to W240_R, but also inferior and practically contained within the distribution of W240_R, indicating that both traits are extending to the same point, with different magnitudes, which shows evidence of the absence
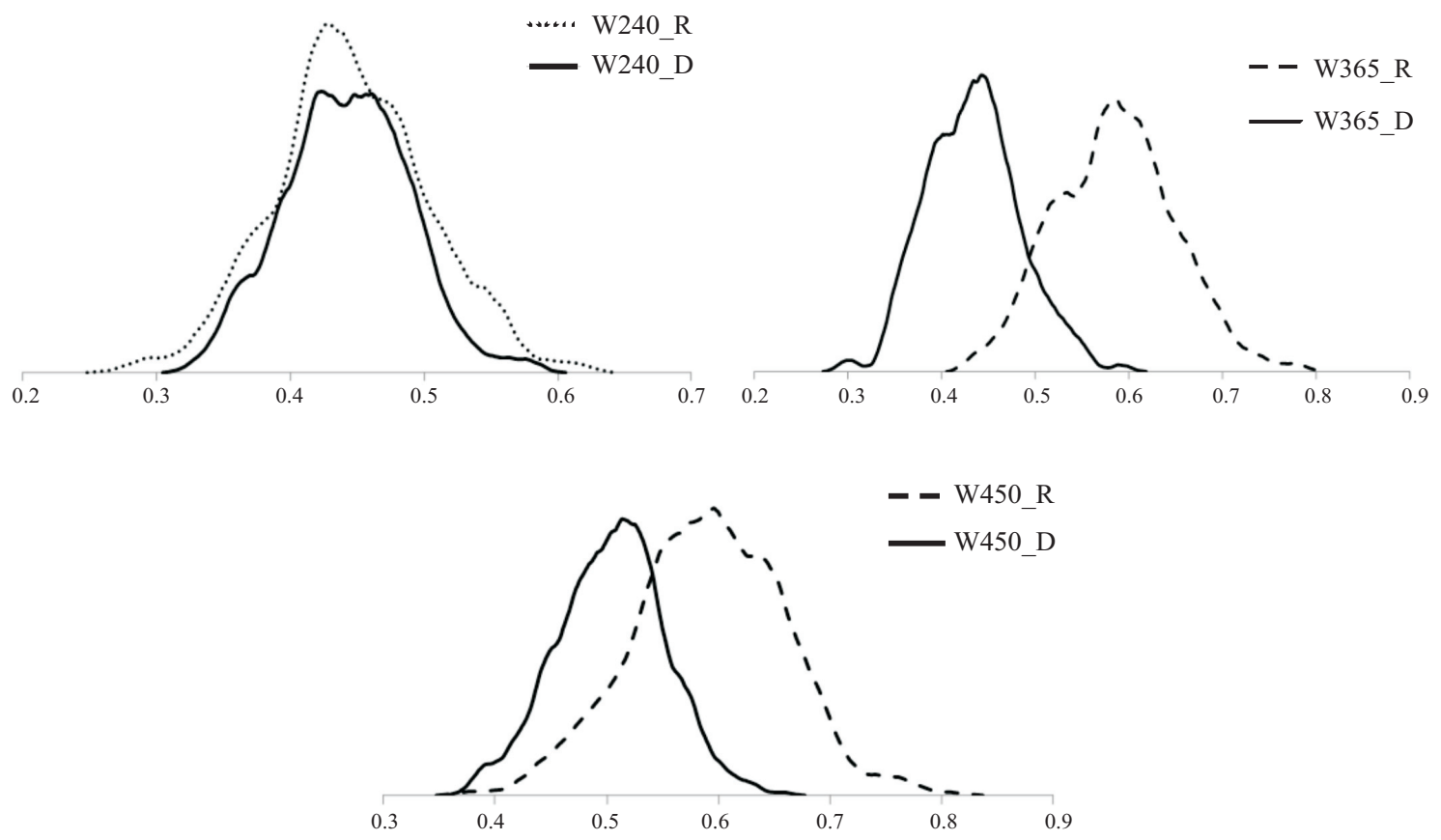

Figure 1 - Posteriori density of heritability estimates (h2) in the x-axis, of 240 (W240), 365 (W365) and 450 (W450) day-old cows during the rainy $(\mathrm{R})$ and dry $(\mathrm{D})$ seasons. 
of GEI, so it can be implied that the different birth seasons were not important to that trait. Mascioli et al. (2006) and Alencar et al. (2005), studying Nellore animals, reported dispersions with lower and inferior magnitudes compared with those in this study.

When the focus was on W365_R, the distribution was superior to that of W365_D. However, the second trait showed higher values, but both varied to the same point, presenting a similar shape (Figure 1). Weights at 450_R had a wider interval distribution of 0.6 when compared with W450_D with amplitude a little bit greater than 0.4; weighing during the rainy season also presented higher values when compared with weights from the dry season of the year.

The dispersion observed in W365 and W450 traits, in both dry and rainy seasons, showed an indication of the presence of GEI, since the phenotype of the individuals is the result of their genotype, which varies according to the environment to which animals are exposed.

Both genotype and environment effects are important to the expression of most of the economic traits in beef cattle. A basic question to the animal breeding field is if selection made in one environment can be valid to reach the genetic progress in another one (Dias et al., 2005, 2006).

When observing the intersection of the densities (Figure 2), the rainy season shows higher genetic variance than the dry one. The difference of variation could indicate that those genotypes are reacting differently to different environments, which implies the existence of GEI.

This is what happens, for instance, if the difference in the weight of animals is more clear in the seasons in which the pasture quality is better on average. In this case, the GEI which resulted from the heterogeneity of variances will not change the classification of the genotypes, but will cause a difference between heritability estimates. However, if a higher variation is a consequence of the difference of variation of the genetic level of herds within each season, which can be caused by the intensity of selection for in some traits during some seasons, then the difference in genetic variation cannot characterize GEI.

The main consequence of that kind of GEI on genetic gain in herds, when evaluated together, is that if there is an intense selection, there can be higher contribution of the season with a higher genetic variation, in this case, the rainy season. So the genetic gain would be reduced, since it is not necessary to choose animals that came from the season with a higher variation, which would not necessarily be the genetically superior animals during all seasons.

Another result (Figure 2) is that the posterior densities of the additive genetic variances from W240_R and W240 $\mathrm{D}$, which are in agreement with the heritability distribution, show similar magnitudes and amplitudes between each other.
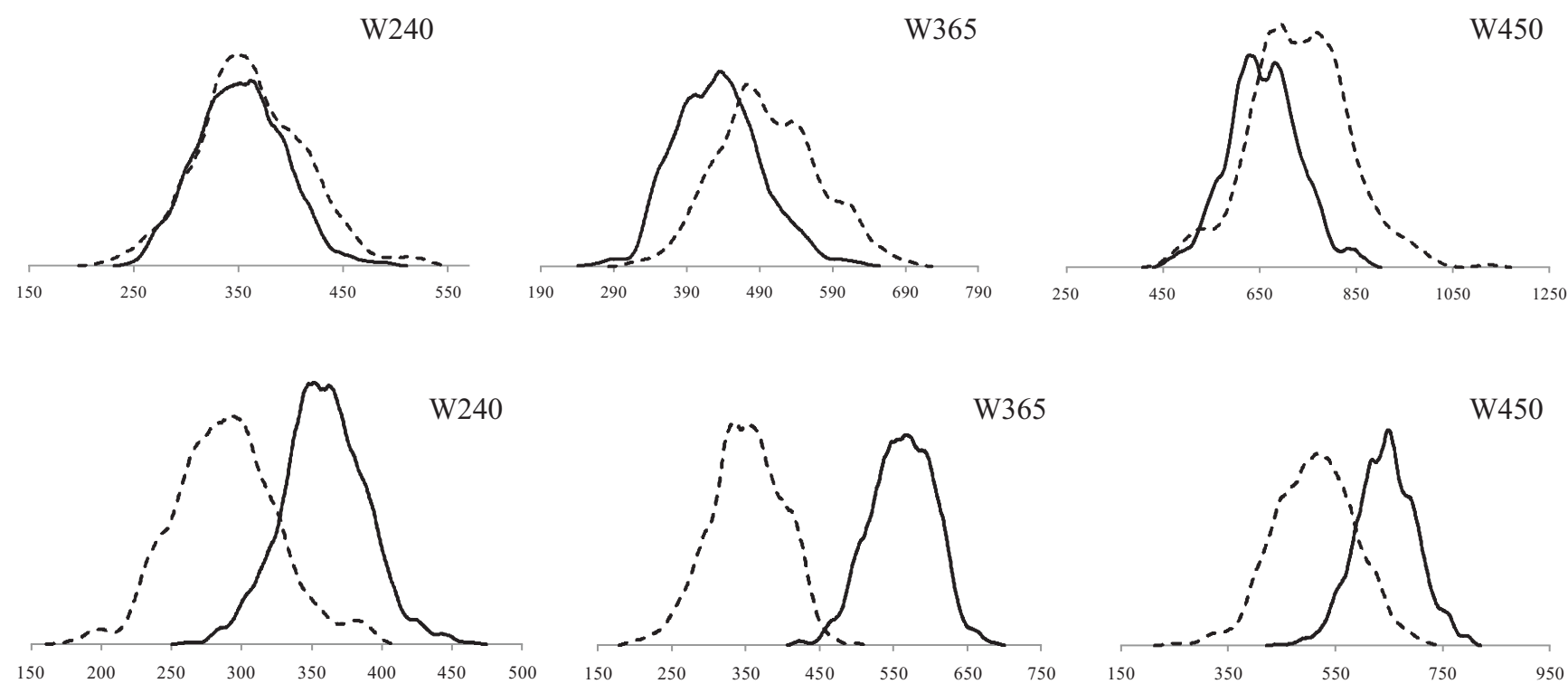

Figure 2 - Posterior density of additive variances (superior) and residual variances (inferior) in the weight of cows at 240 (W240), 365 (W365) and 450 (W450) days during the dry (continuous line) and rainy (dashed line) seasons. 
As for W365_R, W365_D, W450_D and W450_D, all of them showed similar distribution to the heritability estimates considered. When the residual variances are evaluated (Figure 2) the dry season presents the lowest values, whereas the rainy season presents similar distributions between the weights. A lower value of residual variance could be due to a lower environment variation, which can represent better care of and reliability on the data collection.

On the other hand, those values can also be caused by the reaction of some genotypes to some environments within seasons, which can characterize the GEI. If there is a higher variation of quality of pastures within seasons and the magnitude of the differences between the animals depend on the quality of pasture, then the heterogeneity of variance characterizes the GEI (Diaz et al., 2011a).

The residual heterogeneity of variance has also effect on genetic gain when the selection intensity applied is high. Selection of more animals in the season that have higher residual variance is not desirable, since in a practical manner, animals from seasons with less "controlled" environments could be chosen (Diaz et al., 2011b).

Concerning the selection of animals using the phenotype, it is possible to observe that when the heterogeneity of variances is ignored and the intensity of selection is high, there is a tendency to select animals from herds in which the variance is higher, since that is the kind of herds in which animals with extreme values can be found. When selection is based on pedigree information, measures coming from herds that present more variation get more attention during genetic evaluation (Dias et al., 2005, 2006).

Weights at 240 days, in the rainy and dry seasons, presented considerable intersection on their distribution, which indicates the existence of GEI (Figures 1 and 2). However, in other studied traits, those areas of intersection, i.e., common areas for the studied weights during the two seasons, are smaller than the first one, which represents that there are more differences between the rainy and dry seasons.

Therefore, it is possible to verify that these results confirm the importance of including the birth season in the genetic analysis, to get the maximum of accuracy of prediction of the breeding values and they also suggest that genetic evaluation in different regions, with a large environmental difference, will be more efficient to identify genetically superior animals (Corrêa et al., 2007).

Based on the fact that the genotype $x$ environment interaction can have a negative effect on the genetic gain of populations from the Northeast of Brazil, since sires will be inappropriately used, it is highly recommended to consider all the environmental effects existing in all regions, as the ones found in this study.
More emphasis has to be given to GEI when a genetic material is imported, with high investments, since the performance of the animals will be different because the environment in which they will be tested will be very different from the one in which they were selected. Therefore, it is recommended that only animals that are genetically superior and that were tested under the same environment conditions be used to get higher genetic gains in the whole population.

\section{Conclusions}

There is genotype $\times$ birth season interaction on weight at 365 and 450 days of age. The same effect was not found for weight at 240 days in the northeast region considering Tabapuã animals. Genetic evaluation of both weights at 365 and 450 days could be done separately from weights at 240 days of age when the interaction has to be accounted for different birth seasons in Tabapuã animals from the northeastern states of Brazil. It is important to consider the effect of genotype by environment interaction on evaluations to all the growth traits in a Tabapuã population from the northeast; it is also highly recommended that more research with Tabapuã animals be done in other regions of Brazil.

\section{References}

ASSOCIAÇÃO BRASILEIRA DE CRIADORES DE ZEBUÍNOS - ABCZ. Associações e criadores da raça Tabapuã sempre alertas ao melhoramento genético animal. Available at: $<$ http://www.braziliancattle.com.br/?abcz/racas/index $>$ Accessed on: Sept. 17, 2010.

ALENCAR, M.M.; MASCIOLI, A.S.; FREITAS, A.R. Evidências de interação genótipo $\mathrm{x}$ ambiente sobre características d crescimento em bovinos de corte. Revista Brasileira de Zootecnia, v.34, n.2, p.489-495, 2005.

BALIEIRO, J.C.C.; LOPES, P.S.; ELER, J.P. et al. Efeito da heterogeneidade de variância na avaliação genética de 29 bovinos da raça Nelore. I. Análises de uni-caracteristicas para ganho de peso em 30 escala original e transformada. In: SIMPÓSIO DA SOCIEDADE BRASILEIRA DE MELHORAMENTO ANIMAL, v.5, Pirassununga. Anais... Pirassununga: UNESP: 2004. (CD-ROM).

CARDELLINO, R.; ROVIRA, J. Mejoramiento genetico animal. Montevideo: Editorial Hemisferio Sur, 253p. 1987.

CORRÊA, M.B.B.; DIONELLO, N.J.L.; CARDOSO, F.F. Efeito da interação genótipo-ambiente na avaliação de bovinos de corte. Revista Brasileira de Agrociências, v.13, n.2, p.153-159, 2007.

DIAS, L.T.; ALBUQUERQUE, L.G.; TONHATI, H. et al. Estimação de parâmetros genéticos para peso em diferentes idades para animais da raça Tabapuã. Revista Brasileira de Zootecnia, v.34, n.6, p.1914-1919, 2005.

DIAS, L.T.; ALBUQUERQUE, L.G.; HUMBERTO, T. et al. Estimação de parâmetros genéticos para peso do nascimento aos 550 dias de idade para animais da raça Tabapuã utilizando-se modelos de regressão aleatória. Revista Brasileira de Zootecnia, v.35, n.5, p.1915-1925, 2006. 
DIAZ, I.D.P.S.; ARAUJO NETO, F.R.; MARQUES, L.A.M. et al. Interação genótipo $\mathrm{x}$ ambiente e características pré-desmama em animais da raça Simental em duas estações de nascimento. Pesquisa Agropecuária Brasileira, v.43, n.3, p.323-330, 2011a.

DIAZ, I.D.P.S.; OLIVEIRA, H.N.; BEZERRA, L.F. et al. Genotype by environment interaction in Nelore cattle from five Brazilian states. Genetics and Molecular Biology, v.34, n.3, p.435-442. $2011 b$.

FALCONER, D.S. The problem of environment and selection. American Naturalist, v.86, p.293-298, 1952.

FERRAZ FILHO, P.B.; RAMOS, A.A.; SILVA, L.O.C. et al. Environmental and genetic influencing pré and post-weaning growth traits of tabapuã cattle in Brazil. Archives of Veterinary Science, v.6, n.2, p.19-30, 2001.

FRIDRICH, A.B.; SILVA, M.A.; FRIDRICH, D. et al. Interação genótipo ambiente em algumas características de produção de bovinos de corte da raça Tabapuã. In: REUNIÃO ANUAL DA SOCIEDADE BRASILEIRA DE ZOOTECNIA, 40., 2003, Santa Maria. Anais... Sociedade Brasileira de Zootecnia, 2003.

GRESSLER, S.L. Estudo de fatores ambientais e parâmetros genéticos de algumas características reprodutivas em animais da raça Nelore. 1998. 150f. Dissertação (Mestrado em Medicina Veterinária) - Escola de Veterinária/Universidade Federal de Minas Gerais, Belo Horizonte.

HAMMOND, J. Animal breeding in relation to nutrition and environment conditions. Journal of Animal Science, v.22, n.2, p.195-213, 1947.

HEIDELBERGER, P.; WELCH, P.D. Simulation run length control in the presence of an initial transient. Opns Res, v.31, p.1109-1144, 1983.

LOPES, J.S; RORATO, P.R.N; WEBER, T. Efeito da interação genótipo ambiente sobre o peso ao nascimento, aos 205 e aos 550 dias de idade de bovinos da raça Nelore na Região Sul do Brasil. Revista Brasileira de Zootecnia, v.37, n.1, p.54-60, 2008.
MASCIOLI, A.S.; ALENCAR, M.M.; FREITAS, A.R. et al. Estudo da interação genótipo-ambiente sobre características de crescimento de bovinos de corte utilizando-se inferênica bayesiana. Revista Brasileira de Zootecnia, v.35, n.6, p.2275-2284, 2006.

MISZTAL, I. 2009. BLUPF90 and related programs (BGF90). Available at: $<$ http://nce.ads.uga.edu/ ignacy/newprograms.html $>$. Accessed on: Jan. 10, 2010.

PAULA, M.C.; MARTINS, E.N.; SILVA, L.O.C. et al. Interação genótipo $\times$ ambiente para produção de leite de bovinos da raça Holandesa entre bacias leiteiras no estado do Paraná. Revista Brasileira de Zootecnia, v.38, n.3, p.467-473, 2009.

PEREIRA, M.C.; MERCADANTE, M.E.Z.; ALBUQUERQUE, L.G. et al. Estimativas de parâmetros genéticos de características do crescimento em um rebanho Caracu selecionado para peso ao sobreano. Revista Brasileira de Zootecnia, v.35, n.4, p.1669-1676, 2006.

ROBERTSON, A. The sampling variance of the genetic correlation coefficient. Biometrics, v.15, n.3, p.469-485, 1959.

SAKAGUTI, E.S.; SILVA, M.A.; QUAAS, R.L. et al. Avaliação de bovinos jovens da raça Tabapuã, por meio de análises de funções de covariância. Revista Brasileira de Zootecnia, v.32, n.4, p.864-874, 2003.

SMITH, B.J. boa: An R Package for MCMC output convergence assessment and posterior inference. Journal of Statistical Software, v.21, n.11, p.37, 2007.

SOUSA JÚNIOR, S.C.; ARAÚJO NETO, F.R.; OLIVEIRA, H.N. et al. Estimação bayesiana de componentes de (co)variância de características ponderais na raça tabapuã. Revista Brasileira de Saúde e Produção Animal, v.45, n.7, p.1037-1045, 2011.

SOUSA JÚNIOR, S.C.; OLIVEIRA, S.M.P.; ALBUQUERQUE, L.G. et al. Estimação de funções de covariância para características de crescimento da raça Tabapuã utilizando modelos de regressão aleatória. Revista Brasileira de Zootecnia, v.39, n.5, p.1037-1045, 2010 . 